

\section{Rethinking the mechanism of the Social Impact Assessment with the 'Right To the City' concept: a case study of the Blue House Revitalization Project in Hong Kong (2006-2012)}

\section{Dr Kin Wing Chan}

Cardiff School of Planning and Geography

Glamorgan Building King Edward VII Avenue

Cardiff Wales CF10 3WA;

Email: Chank16@cardiff.ac.uk

Post-print. Accepted in Journal of International Planning Studies on $12^{\text {th }}$ December 2016

\section{Highlights of the paper:}

- This paper elucidates how a group of researchers, social workers and affected residents sought to claim their 'right to the city' in a renewal project in $\mathrm{HK}$.

- The Blue House case is a collective action outcome to challenge the dominant discourse of project-induced displacement and reclaims affected residents' collective rights to develop more inclusive space for themselves.

- To a small extent, the SIA mechanism can effectively mitigate the social impacts of urban renewal in HK.

\section{Acknowledgements.}

I would like to thank Yeung Chi Wai, Alan Smart, Tang Bo Sin, Byron Miller, and Janice Tse for helpful comments on an earlier draft of this manuscript. I would like to thank Gareth Enticott, Tang Wing Shing, Martha Cook, Maria Lam Lai Ling, for encouragement and Wong Sau Ping for assistance with data collection in Wan Chai Hong Kong. Thanks also go to reviewers and editors to provide insightful comments for this paper. 


\title{
Rethinking the mechanism of the Social Impact Assessment with the 'Right To the City' concept: a case study of the Blue House Revitalization Project in Hong Kong (2006-2012)
}

\begin{abstract}
Over the past two decades, urban renewal has become a major means to increase the efficiency of land production in Hong Kong (HK). Although the Urban Renewal Authority (URA) and Hong Kong Housing Authority (HKHA) have introduced the social impact assessment (SIA) mechanism to mitigate the social impact of renewal projects, social conflicts have intensified between affected residents and the URA/HKHA. To what extent can SIA effectively mitigate the social impacts of urban renewal in Hong Kong HK? To answer this question, the author draws on a mixture of empirical and secondary materials to analyse the development, assessment procedures and report format of SIA in $\mathrm{HK}$ as a basis to evaluate the challenges of this mechanism. Then the author goes on to critically analyse how thinking on 'right to the city' and affected residents' comments come together to inform reflections on SIA in HK. The author argues that the SIA mechanism in HK remains technocratic in nature because it does not function effectively in addressing the needs of affected residents and resolving the deep-rooted conflicts between residents' right of living and pro-growth development.
\end{abstract}




\section{Introduction}

Facing the problem of urban decay, in 2001 the Urban Renewal Authority (URA) delivered an Urban Renewal Strategy (URS) to guide urban renewal projects. Under the URS, the URA is required to conduct social impact assessment (SIA) to alleviate potential undesirable social impacts on affected communities before launching any renewal projects. According to one URA staff member,

We have followed the Urban Renewal Strategy to conduct SIA to assess the impact of a proposed project and the SIA report has been submitted to the Town Planning Board.... the URA not only provides mitigation measures but also arranges social workers to address affected residents' needs (Town Planning Board, 2006, 31-32).

However, affected residents perceive SIA mechanism as "a legitimization process for property development" (In-depth interview, BH003, 2013) and a "political show to cover social conflicts" (In-depth interview, KT002, 2008). These contradictory views provide an apt entry point for this paper to examine the effectiveness of the SIA mechanism to mitigate social impacts of renewal projects in Hong $\mathrm{Kong}(\mathrm{HK})$. This paper has two major objectives: (1) to evaluate the effectiveness and challenges of SIA in the Blue House Revitalization Project in HK and (2) to inform reflections on SIA by incorporating thinking on Henri Lefebvre's 'right to the city' concept and comments from affected residents.

The empirical materials in this paper were collected between 2008 and 2013, during which the authors developed links with affected residents, social workers, government officials and policy makers. The authors conduced in-depth interviews with key actors, including URA staff, affected residents, and social activists. According to Creswell $(2007,131)$ conducting in-depth interviews helps this research to "describe the meanings" of SIA mechanism from a group of people "who have experienced it". Indepth interview questions are semi-structured in order to increase the flexibility of the ways in which questions are asked and answered (Denzin and Lincoln 2005). Questions were used to examine the understandings of affected residents, government officials and social workers of the SIA mechanism - for example, "Describe to me, how do you understand the purposes of social impact assessment in the Blue House Revitalization 
project?". Additionally, the authors participated in the government's public hearings and residents' monthly meetings to observe how affected residents interact and negotiate with the URA and Housing Authority staff (Dooling 2009, 634). Apart from gathering primary data, the authors conducted archival research by collecting development proposals, policy documents, and reports from the Hong Kong Legislative Council (HKLC), Hong Kong Housing Authority (HKHA), Town Planning Board (TPB) and URA to analyse the practices and strategies of the SIA mechanism in HK.

This paper is divided into two parts. Following the introduction, in part one the author discusses the concept of SIA and elucidates how the concept of 'right to the city' can enrich the rights-based approach in SIA. I do this by introducing the concept and implications of SIA in dealing with proposed development, resettlement, and human rights issues. Then the author discusses how the thinking on 'right to the city' and affected residents' perceptions come together to inform thinking on SIA in HK. In part two, the author provides a detailed analysis of the assessment procedures and report format of the SIA mechanism in HK. By using the Blue House Revitalization Project as a case study, I demonstrate the challenges and contradictions between urban renewal and affected residents' needs in the SIA mechanism. Finally, the author will discuss the implications of the 'right to the city' in considering urban futures and provide policy recommendations to improve SIA practices in HK.

\section{Part One: The concept of Social Impact Assessment}

The term SIA refers to the "processes of analyzing, monitoring and managing the intended and unintended social consequences, both positive and negative" of development projects (Vanclay et al. 2015, 1). To evaluate the socio-economic impacts of

development projects, urban planners have adopted SIA to alleviate developmental impacts, understand different stakeholders' perceptions, and promote social justice at large (Cooke and Kothari 2001; Ng and Hui 2007; Taylor et al. 2004). Through this riskassessment method, urban planners can develop comprehensive qualitative and quantitative indicators to estimate, predict, and report on any social changes associated with development projects (Vanclay 2003; Vanclay et al. 2015). Although the concept of SIA has been widely applied in the planning field, practitioners keep critically rethinking 
the concept, procedure, and practice of SIA. To engage stakeholders in the analysis of social impact, Lockie (2001) suggests that SIA practitioners should consider conflicting interests and values among stakeholders in the development project. Vanclay et al. (2015, 20) further explain that practitioners can (1) provide better understandings of the local values and experiences of different stakeholder groups; (2) help affected residents understand the planned intervention and its implications; and (3) invite affected residents to enhance the design of the development projects. Drafting an Impact and Benefit Agreement (IBA) is one of the effective ways in which SIA practitioners can involve affected stakeholders effectively in the decision making and planning of mitigation processes. The IBA is a legally-binding agreement among the community, a developer, and the government to co-produce an understanding of expected negative impacts, mitigation measures, and the social investments that the developer and government will contribute (Vanclay et al. 2015, 85). For instance, the government of Northwest Territories in Canada negotiated with developers and aboriginal communities by drafting an IBA to create more room for indigenous communities to participate in development projects and dispense development benefits and social responsibilities more equitably (Caine and Krogman 2010; Galbraith et al. 2007; O'Faircheallaigh and Corbett 2005). The IBA provides an effective participation method to consider communities' interests, to develop guidelines for development-induced displacement, and to provide on-going monitoring of potential social impacts (Vanclay and Esteves 2011). The reflections of IBA provide insights for this research to evaluate whether the practice of SIA in HK can provide an effective participation mechanism to engage affected residents in "decisionmaking processes that are meaningful to them" (Vanclay et al. 2015, 22). For development induced displacement, there is a strong emerging international understanding of the principles which SIA practitioners should consider: (1) avoid or minimize displacement by exploring alternative project designs, (2) avoid forced eviction by using negotiated agreements, (3) anticipate adverse social, economic and human rights impacts; and (4) provide appropriate disclosure of information and allow for the informed participation of those affected (Vanclay et al. 2015, 25). In practice, SIA practitioners not only consider monetary compensation for affected communities but also provide social assistance, trainings, and develop a Resettlement Policy Framework (RPF) to restore 
affected communities' livelihoods and living conditions (Vanclay et al. 2015, 24). The RPF outlines the project's policy and general procedure regarding how land acquisition, resettlement, compensation, and livelihood restoration and enhancement will be undertaken (Vanclay et al. 2015, 25). There should be a detailed Resettlement Action Plan (RAP) for enacting the process of resettlement and providing a mechanism for determining who is eligible for compensation (Momtaz 2006). The urban renewal in HK connects with the discourse of project-induced displacement and resettlement; the reflections of international principles pertaining to resettlement and compensation provide insights for this study to evaluate the effectiveness of the SIA in the Blue House Revitalization Project to deal with affected residents' housing needs.

To ensure best practice of SIA, commentators also suggest that the skillset of SIA practitioners should be expanded to (1) consider the human rights issues of affected residents under the United Nations Guiding Principles on Business and Human Rights (Götzmann et al. 2016); (2) adopt multi-level analysis (e.g. local, national, and regional) to understand the complexity of actors' interactions in the development; (3) consider good governance practices to steer both natural and human resources to achieve more positive policy outcomes (Vanclay and Esteves 2011); and (4) consider social impacts from the local context and devise community-led development plans (Vanclay et al. 2015).

\section{Incorporating 'Right to the City' concept to enrich the rights-based approach in SIA}

Although both the rights-based approach in SIA and Henri Lefebvre vision of 'right to the city' seek to develop more democratic and equal urban futures (Mayer 2012), the principles of SIA stress individual unity for human rights. However, the Lefebvrian vision understands 'rights' as collective actions to: (1) challenge the claims of the dominant development discourse (Mayer 2012) and (2) confront the totality of capitalist urbanization through class struggle (Harvey 2008). Although the concept of right to the city emerged under the backdrop of rapid urbanization in France, this concept has been implemented in Latin America (Brown 2013, 1) and written in the World Charter for the Right of City $(2005,2)$ 
It is the collective right of the inhabitants of cities, in particular of the vulnerable and marginalized groups....this assumes the inclusion of the rights to work in equitable and satisfactory conditions; to establish and affiliate with unions; to social security, public health, clean drinking water, energy, public transportation, and other social services; to food, clothing, and adequate shelter; to quality public education and to culture; to information, political participation, peaceful coexistence, and access to justice; and the right to organize, gather, and manifest one's opinion. It also includes respect to minorities; ethnic, racial, sexual and cultural plurality; and respect to migrants.

By Lefebvre's explanation, 'right to the city' is a "superior form of rights: right to freedom, to individualization in socialization, to habit and to inhabit". The right to (the city) as oeuvre, to participation, and to appropriation (clearly distinct from the right to property) are implied in the right to the city (Lefebvre 1996, 173-174). Purcell $(2003,578)$ explains that the city as oeuvre "refers to the city and urban space as a creative product of and context for the everyday life of its inhabitants". In this sense, the value of urban space is to maximize the use value (i.e. house for daily living) rather than to maximize its for exchange value (i.e. house for economic speculation). The 'right to the city' concept, first introduced by Henri Lefebvre in the 1960s, has been promoted in urban policy to deliver collective rights to transform urban policy and futures (Fernandes 2007; Mayer 2009; Mitchell 2003; Omoegun 2015; Purcell, 2002). Although SIA practitioners appeal to protect the human rights of affected groups, current SIA studies have not interrogated how the role of government and the relationship of property produce power of expulsion, leading to social segregation in development projects (Blomley 2004; Staeheli and Mitchell 2008). Particularly, how the state's authority discourse tends to strengthen the power of dominated groups (e.g. real estate developers), whilst further marginalizing unwanted groups (e.g. affected residents) through urban renewal processes.

Incorporating the concept of right to the city (Lefebvre 1996) opens up the theoretical terrain of SIA in three major ways. First, this concept not only helps SIA practitioners and planners to go beyond individualistic and property rights consideration, but it also extends the definition of 'right' as a collective policy outcome within the principle of equity and social justices (Harvey 2012). It not only helps the diffusion of the right to the city concept in SIA practice but also broadens the meanings of 'rights' in SIA theory. Second, the right to the city concept inspires SIA practitioners and planners to 
critically evaluate the role of urban renewal authorities and evaluate the lived experiences of affected people in the development projects. This concept can open up more imaginations for planners to consider alternative urban developments (Tang 2008). This includes developing more public and inclusive urban space for marginalized groups and being aware of the problems of commodification and privatization in urban renewal processes. Third, it supports more Lefebvrian-inspired research in the HK context, with a focus on (1) Henri Lefebvre's production of space to examine the spatial contestations in development projects (Kwok 1998; $\mathrm{Ng}$ et al. 2010) and (2) theoretical reflections on the implications of the Lefebvrian perspective on the non-west urban context (Tang 2014). However, currently there is a lack of study in incorporating thinking on 'right to the city' and affected residents' perceptions to inform thinking on SIA in HK. Empirically, the SIA practice in the Blue House Revitalization Project provides insights for local and international SIA practitioners to understand the process and challenges of the SIA mechanism in HK. Commentators such as Tang et al. $(2012,91)$ critically reflect that the implementation of public engagement exercises in HK "are political technologies" to resolve the contradictions between the relentless demand on lands and the interests of affected residents during such urban renewal process. Tang (2008, 355-356) further explains that urban renewal processes in HK are "the outcome of negotiations between the government and LDC/URA" and "provides a mechanism for sharing the benefits accruing from development. Thus, the government benefits from improvement in the built environment and the URA [benefits] from the maximization of the market potential of redeveloped properties." Tang's argument helps us to critically question whether the assessment and reporting procedures of SIA can effectively address the deep-seated conflicts between affected residents' right to living and pro-growth development - this is discussed in the following section. 


\section{Part two: The assessment procedures and report format in the HK's SIA mechanism}

The assessment procedures of SIA in HK

According to Paragraph 28 of the URS, the URA mainly evaluates the potential social impacts of a proposed project and the re-housing arrangements for the affected residents. The assessment of social impacts is mechanically conducted in two phases: (1) phase one assessment includes conducting a non-obtrusive assessment before the publication of the proposed project in the Government Gazette and (2) phase two assessment includes a detailed assessment after the proposed project has been published in the Government Gazette (Housing, Planning and Lands Bureau 2001). Phase one of the assessment aims to provide a general understanding of the affected community. As stated in Paragraph 30 of the URS, the non-obtrusive assessment comprises a web of elements (e.g. land use and social features) that assess the cultural, socio-economic, and environmental impacts towards the affected community.

Phase two of the assessment explores understandings of the socio-economic backgrounds of the affected residents, particularly the special needs of the elderly and children. To do so, government officials conduct a 'Census and Assets Inventory Review' (CAIR in short) survey and determine eligibility for compensation. Known in HK as a 'freezing survey', information on a wide range of issues (i.e. population and socioeconomic features) and potential impacts (i.e. loss of jobs and social networks) are collected. The 'CAIR' surveys have to be conducted after a proposed project is published in the gazette, as stated in Paragraph 25 of the URS, in order to determine the eligibility of affected residents for compensations, re-housing needs ${ }^{1}$ and in order to evaluate the redevelopment impacts towards the community at large (Figure 1). 


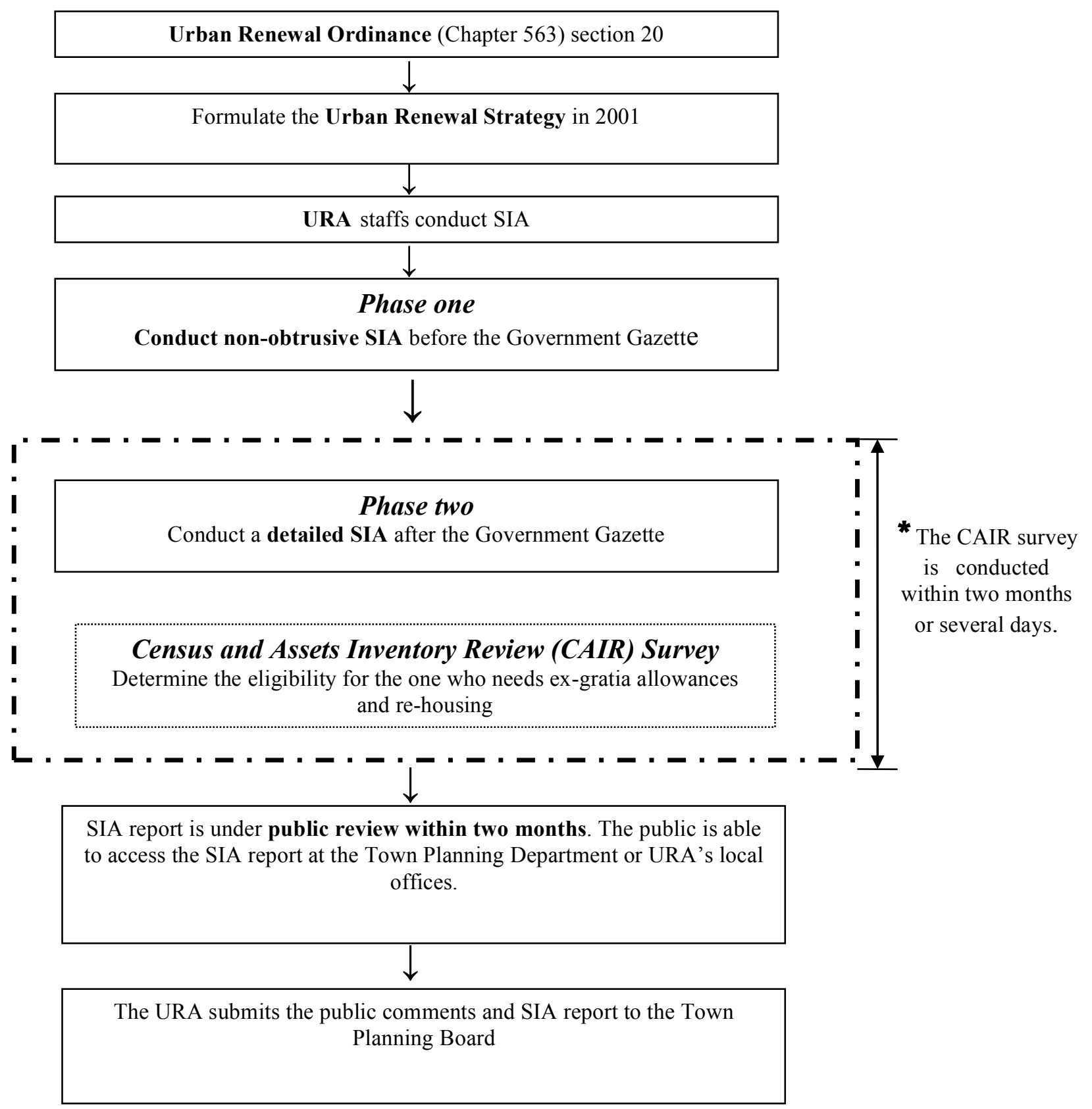

Figure 1: The mechanical assessment procedures of the SIA in HK. Source: (Civic Exchange (2006), Housing, Planning and Lands (2001), The Notice of Gazette H05-026, 2006; Stone Nullah Lane/ The (H05-026) SIA Report (2006) 
The format of the SIA report

The guidelines for URA/HKHA to prepare SIA reports are to identify potential impacts and address these with different mitigation packages. To note, it could be argued that these packages simplify affected residents' problems, and in turn may not sufficiently address their actual needs (see Table 1). As required under Paragraph 31 of the URS, the SIA report examines a number of social aspects including population pattern, socio-economic characteristics, housing requirements, employment conditions, social networks, education needs of the children, and special needs of the underprivileged groups. To respond to these impacts, the function of the SIA report is to provide particular mitigation measures to ameliorate developmental impacts. The common practices of URA/HKHA are to provide financial and rehousing assistance for those affected residents. For example, the Hong Kong Housing Authority (HKHA) will assist the re-housing of those affected residents, while the Education and Manpower Bureau will provide school places for children who are affected by renewal projects (Urban Renewal Authority 2006). The author questions whether re-housing and providing school places sufficiently restores affected residents' livelihood and living conditions? In the following section, the author employs the Blue House Revitalization Project as a case study to further evaluate the effectiveness of the SIA mechanism in HK in addressing residents' needs.

Evaluate the effectiveness and challenges of the SIA mechanism in HK - The Blue House Revitalization Project

According to the HKHS, the Blue House Revitalization Project (H05-026) aims to preserve building heritages and revitalize local communities. The community in this project consists of nine tenement blocks (The Hong Kong Housing Society 2006) and one piece of open space. The Blue House project was named after the external walls of the buildings were painted blue in the 1990s (see Figure 2). 


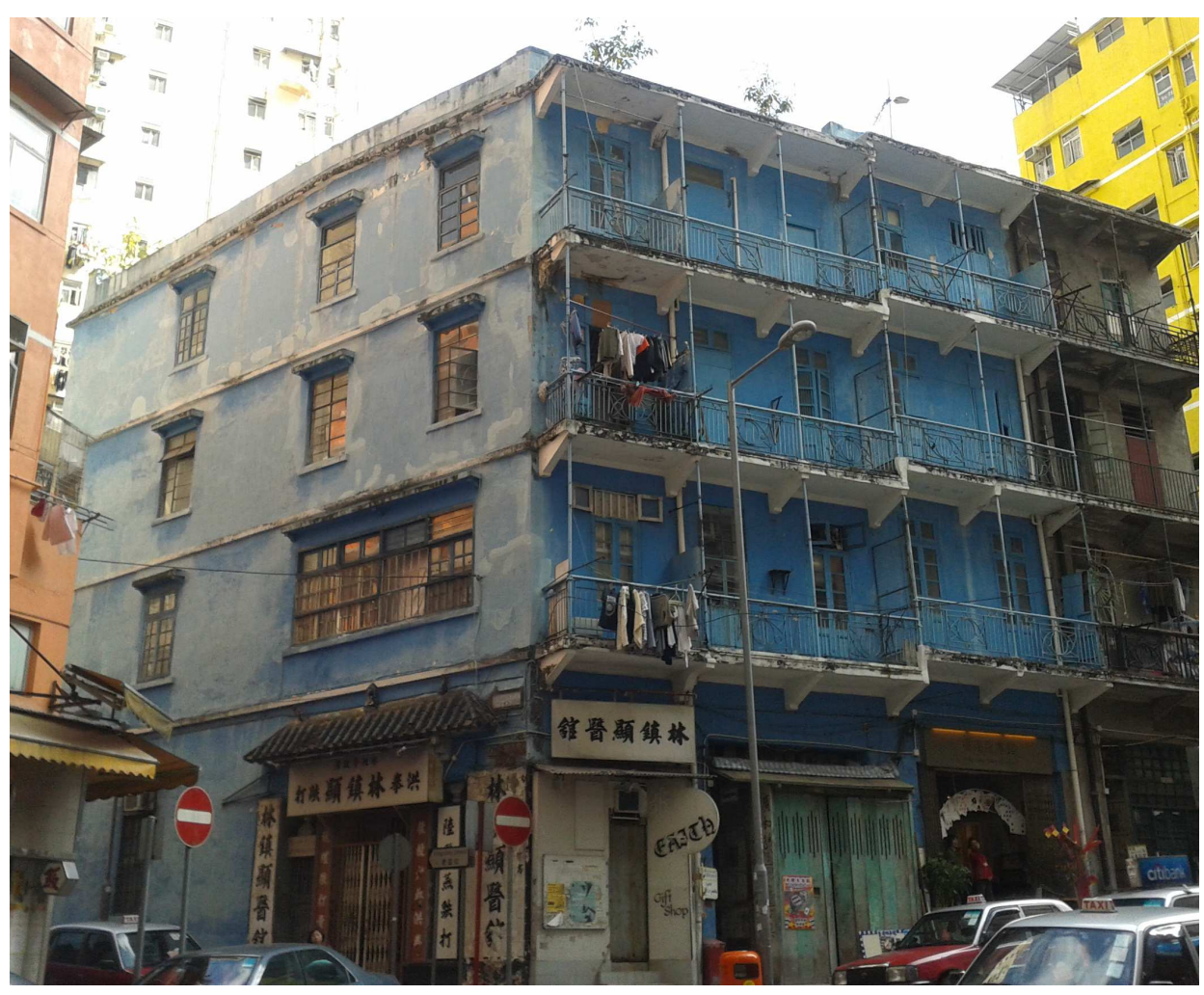

Figure 2. The Blue House

The Blue House is a single four-storey traditional Chinese tenement house, which was built in the 1920s. Under the Antiquities and Monuments Ordinance, the Blue House was preserved and confirmed as a Grade 1 Historic building by the Antiquities Advisory Board in 2010, indicating that the building comprises invaluable historical and cultural values (The Antiquities Advisory Board, 2013). Particularly, these buildings reflect the collective histories of the Chinese medical services, post-war schooling, and chamber of commerce for fishmongers of the community (The Blue House Cluster 2011). Under a partnership between the URA and HKHS, they launched the development scheme of the Blue House project under Section 23 (1) and Section 25 of the URA Ordinances on 31 March 2006 (The Notices of Gazette H05-026, 2006).

The development objectives were to reinvigorate the community through the revitalization of deteriorated buildings and the preservation of historical buildings with architectural merits. The URA and HKHS intended to enhance the heritage values of the project area by preserving the existing structures and architectural details, and promoting local identity and culture (The Hong Kong Housing Society 2006). By reviewing the HKHS's proposal (2006), the proposed development project was to revitalize three 
historical buildings for commercial uses with the themes of traditional Chinese tea and medicine selling. The architectural features, such as wooden window frames and original floor tiles, would be retained, reflecting the previous uses within the project area and the surrounding environment. Work focused solely on the building outlook; according to the Schedule of Uses stated in the Development Scheme Plan (DSP), residential purpose was not included in the project. As a result, this indicated that the scheme area was mainly concerned with commercial purpose and property development to revitalize the area. In other words, the living rights of the affected residents were not considered, and existing residents in these buildings had to be relocated out of the scheme area. It was argued by St. James' Settlement (a local-based social service agency which helps affected residents to negotiate with the URA/HKHS) that the heritage buildings should be preserved as 'a cluster' to preserve both the historic buildings and local community networks - indicative of the fact that the St. James' settlement concerned the 'rights to living' of the tenants. In 2009, the Development Bureau (DEVB) launched the Blue House Cluster Revitalization Scheme (BHCRS), which allows three major Non-Profit-Making Organizations (NPOs) including St. James' Settlement, Community Cultural Concern Institution ${ }^{2}$ and Heritage Hong Kong Foundation Limited $^{3}$ to revitalize the Blue House Cluster. According to the BHCRS, "The tenants who opted to stay in the Cluster, the community network, and other intangible cultural elements are key elements in the preservation and revitalization of the Blue House Cluster" (The Blue House Cluster 2011, 2). When comparing the BHCRS to the URA/HKHA's SIA report, the SIA report had not well considered the willingness of affected residents to continue living in the project site and the possibility to preserve their living style and community network (see Table 1).

Additionally, the development scheme involved the rezoning of the entire precinct to "Other Specific Uses (OU)" - annotated "Open Space and Historical Buildings Preserved for Cultural, Community, and Commercial Uses" (The H-15 Concern Group 2006). It would provide a total of approximately $220 \mathrm{~m}^{2}$ of open space in the project area, which would be obtained through the demolition of existing buildings including Orange House. The rezoning of land use became a conflicting issue between the URA/HKHA and the affected residents. This is because affected residents accused the URA/HKHA of gentrification and the privatization of open space for commercial use through rezoning 
(H-15 Concern Group 2006). Although two phases of the SIA have been launched, there are disparities in the consideration of residence needs, social networks and public consultations between the URA/HKHA report and the needs of the affected residents (see Table 1). By reviewing the summary of 53 residents representatives' comments in Town Planning Board Paper No. 7724 on the Blue House project, resident representatives responded that the SIA report is inadequate to address the needs of affected residents because it did not consider affected residents' choice to stay (see Table 1, column 1). Concerning the impacts on social network, the SIA report informed that there is a "likely impact' on social network; however, by contrast, all of the resident representatives commented that the SIA report did not emphasis on the preservation of community network (see Table 1, column 2). Although the SIA report stated that mainly affected residents are interviewed, the resident representatives questioned about the effectiveness of public consultation in the SIA mechanism by claiming that there is lack of 'extensive' public consultation and communication with the affected stakeholders (see Table 1, column 3).

Table 1. Comparing the overview of impacts assessed in SIA report with the summary of affected residents' needs:

\section{SIA report}

(1) Impacts on URA/HKHA informed "the existing residence compensation and rehousing policies and procedures of the URA are reasonably sufficient to mitigate the impact on residents (The H05-026: SIA report, 2006, 15, my emphasis)."

\section{Affected residents' needs}

Resident representatives No.1 to $41,43,46$ and 48' commented: "The SIA is inadequate to address the concern of the affected community. Residents are only allowed to choose between rehousing and compensation. They should be offered a choice to stay (TPB Paper No. 7724 on 8.12.2006, 3, my emphasis)."

(2) Impacts on URA/HKHA explained "there is a likely social impact on affected residents' social network networks...there is a need to help affected residents to find and adopt to new community (The H05-026: SIA report, 2006, 9-10, my emphasis)."
Resident representatives No.1 to 53 commented: "There is no emphasis on the preservation of the living style and community network of the grass-roots. Representatives request a more effective SIA should be conducted (TPB Paper No. 7724 on 8.12.2006, 3, my emphasis)." 

(3) Adequacy
of public
URA/HKHA described mainly affected
Resident representatives No.1 to $35,43,46$
consultation residents are interviewed, "among the 14
surveyed units, $28(51 \%)$ out of a total of
55 households were interviewed and their
and 48 commented: "There is a lack of
opinion and data formed the basis of [the]
extensive public consultation and
SIA report (The H05-026: SIA report, communication with the affected stakeholders and the public (TPB Paper No. 7724 on 2006, 3, my emphasis)."

The Blue House's affected residents launched the counter-proposal

In response to the contrasting views with the SIA report and HKHS/URA development scheme, the Blue House Community Preservation Committee (BHCPC), comprised of Blue House residents' representatives, academics, social workers from the St. James' Settlement, ${ }^{4}$ and some members of the Wan Chai District Board, launched a counter-proposal to claim the 'rights to living' for the affected residents. Particularly, the BHCPC conducted various public consultations, focus group meetings, and workshops to explore the principles of community conservation and exercise the right to the city concept (Tang et al. 2009; H-15 Concern Group 2006). In BHCPC, there were complimentary roles among academics, social workers, and residents' representatives to develop and exercise the concept of right to the city. The academics introduced the concept of right to the city to inspire the community to reclaim their 'rights to living' through workshops and focus group meetings; while the social workers and residents' representatives provided leadership to organize community members to reclaim their 'rights to living' through organizing social campaigns and demonstrations, and challenging URA/HKHA's proposals in public forums and hearings. Social workers and residents' representative even went further to establish the 'Blue House Living Museum' and organize 'community tour' to demonstrate the cultural landscapes and introduce the 'rights to living' to the general public in HK. Finally, BHCPC not only opened up a new possibility for affected residents to reclaim their rights to the city but they also coproduced a counter proposal to demand 'rights to living', 'rights to participate in planning design', and 'rights to monitor the SIA process' in the Blue House Revitalization Project. Although two phases of the SIA have been launched, the considerations of the residents' 'rights to living' and 'rights to participate in planning design' are not well addressed in the URA/HKHA's mitigation measures in the SIA reports (see Table 1). Therefore, the 
BHCPC's counter-proposal questioned the meanings of revitalization and whether it should include considerations of the (1) living rights of the affected residents and (2) allowing affected residents to return to the Blue House after revitalization. The affected residents and BHCPC did not accept the development scheme proposed by the URA and HKHA. This pushed the Blue House Revitalization Project into a seesaw battle. According to one local activist,

Until 2009, the URA/HKHS finally gave up the Blue House Revitalization Project and transferred the development plan to the Development Bureau (DEVB). The DEVB invited non-profit organizations to bid for the Blue House project. As a result, there were totally three non-profit making organizations NPOs) submitted tenders for the Blue House project (In-depth interview, ID: BH003, 2013) (Direct Translation).

Until mid-2009, the DEVB accepted the affected residents' proposal of "retaining the buildings and its sitting tenants" and allowed an NPO to bid for the project and join hands with the government to revitalize the Blue House Cluster (The Blue House Cluster 2011, 1). In August 2009, the Secretary for DEVB granted an approval-in-principle to the St James' Settlement-Viva Blue House Project (VBHP) (The Hong Kong Legislative Council 2010,3). This restarted the revitalization of the Blue House cluster under a partnership scheme between the DEVB, the St. James' Settlement, and the affected residents. The Viva Blue House Project (VBHP) aims at reclaiming the 'living right' of affected residents by offering affordable housing after revitalization. Additionally, the VBHP also provides affected residents with the 'rights to participate in the planning design' by (1) establishing a unit for exhibition and research about the importance of protecting 'rights to living' under pro-growth development in HK and (2) developing community-centered restaurants and community markets (The Hong Kong Legislative Council 2010, Appendix A, 10-11). All in all, the VBHP not only challenges the URA/HKHA's development scheme but also demonstrates a collective action among affected residents, academics, and social workers to reclaim their 'rights to living' and 'rights to participate in planning design'. Without the collective actions of affected residents, social workers, and academics in determining the kind of future development plan they want, affected residents would alternatively need to be rehoused or relocated by the URA/HKHA. 
By critically reflecting on the Blue House Revitalization Project with affected residents' comments and the right to the city concept, this study identifies five major challenges for the SIA mechanism in HK:

\section{Lack of sound assessment requirement and dependability}

Under the Urban Renewal Strategy (URS), SIA provides only general guidelines and principles. The phrase of SIA is not specifically stated within the Urban Renewal Authority Ordinance (URAO); instead the word "assessment" is used. For instance, under the URAO section 25 3B para $6(2001,11)$,

an assessment by the Authority as to the likely effect of the implementation of the development project including, in relation to the residential accommodation of persons who will be displaced by the implementation of the development project, an assessment as to whether or not, insofar as suitable residential accommodation for such persons does not already exist...

Under the URS, the URA "should assess the impact of a proposed project" and "should be carried out in two phases". However, there is lack of sound assessment requirement for the evaluation outcome because "there is no specific government department responsible to conduct SIA and provide opinions to the town planning board" (TPBcomment from the representative, 2006, 29). Furthermore, when questioned about the amendment of the Development Scheme Plan (DSP), the TPB replied to the community representative - "implementation issues such as rehousing, compensation and acquisition were outside the ambit of the Town Planning Ordinance and purview of the Board" (2007, 34). Without clearly defining the SIA's procedures, methods, and report formats of the SIA in the URAO or Town Planning Ordinance, there is room for the URA and HKHS to interpret the principles and guidelines of SIA according to its value and judgement.

Also worthy of note is that the SIA is commissioned by the URA and HKHS itself rather than by independent third parties. In practice, on the date on which a project commences, the URA and HKHS staffs will conduct both the "Census and Assets Inventory Review (CAIR) ${ }^{5}$ " survey and SIA at the same time. According to the URS (2011, 15), a CAIR survey is a questionnaire used by the URA to examine the occupation status of property and determine whether the owner is entitled to receive compensation for property acquisition. When the CAIR survey and SIA are commissioned 
simultaneously, this arrangement can cause confusion to the affected residents because both SIA and the CAIR survey are two separate studies, which fundamentally serve different purposes. Functionally, the purpose of the CAIR survey is to identify and register those "legal residents" who are living in the development scheme area. However, the purpose of SIA is to "assess the social impact of a proposed project and the social and rehousing needs of the residents affected" (URS 2011). When asked about the meanings and differences of the SIA and CAIR survey, one affected resident answered, "I am not sure when the CAIR survey was conducted.... Well, I just remembered some government staffs came to fill out the forms with me" (In-depth interview, ID: BH001, 2006). In fact, the above interview reflected that both the SIA and CAIR surveys are confusing and even affected residents did not realize that SIA had been conducted. A crosschecking interview was conducted with one Blue House activist, who said,

There are four major drawbacks of the SIA mechanisms in the URA and HKHS's blue house project: firstly, there was too short period of time to conduct the SIA, specifically the survey was only conducted within two days. Therefore, some residents might not be interviewed or ignored due to this short conducting period. Secondly, there was no alternative for residents to retain their rights to stay and the only option was to relocate them to public housing estates....the CAIR survey acted like a legitimization process to facilitate the residents' rehousing process though some residents were reluctant to move. Thirdly, there was a confusion to conduct both SIA and CAIR survey together because one was an assessment of the development toward the community at large, while the CAIR survey emphasized the rehousing assistance but without considering the social networks and living rights of the affected residents (In-depth interview, ID: BH003, 2013) (Direct Translation).

From the above activist's comments, the major problem of the SIA mechanism in the Blue House project was that it was unable to retain the 'living right' of the affected residents, whilst the CAIR survey was conducted in a short period of time without considering social networks. Therefore, local residents and activists both questioned the legitimacy of the SIA process in the Blue House project. Even affected residents required URA/HKHA to re-conduct a more effective SIA and take into account the project's surrounding areas (see Table 1). 
The challenges for the social workers' team to mitigate the social impacts

There are dilemmas and challenges for the URA and HKHA's social worker team to mitigate the social impacts of the development project. In response to the criticism that the community interests were overlooked in the past urban redevelopment projects, social service teams were set up to provide assistance to the affected residents in the Blue House project under the contracts with the URA and HKHA. According to the (H05-026) SIA's Report, the HKHS listed crucial remedy measures to tackle those forecasted social impacts - "The services offered by the social service team are reasonably sufficient to mitigate the impact on residents, business operators, and their employees" $(2006,15)$. Hence there are concerns about whether the social service teams can work independently to cater for the needs of the affected residents while satisfying the missions given by the URA and HKHA. One of the social workers commented,

Sometimes we acted like a cushion to responses both the needs of the affected residents and the URA's projects' principles and guidelines... we feel confusions in our roles and duties as social workers. And we experienced the dilemma and tension between preserving the community values and rehousing those affected residents. (In-depth interview, ID: KT 001, 2006, Direct Translation)

Under such contractual relationships with the URA and HKHA, the social service team becomes the scapegoat for blaming any mishandling of resettlement, unfair compensation, and upsetting living rights for the affected dwellers. In reality, the social service team serves as a buffer to distance the URA and HKHS from direct conflict with affected residents.

\section{Narrow scope of assessment}

The scopes of SIA practices in HK are narrow and the assessment variables are subjected to the URA and HKHS's preferences. These variables include quantified population characteristics, socio-economic features, re-settlement consideration, employment information, and the social networks of the affected residents ((H05-026 SIA report 2006). The SIA reports incline toward quantitative analysis and enumerate the result in measurable indicators. As pointed out by the social worker who served the local district, 
The current SIA mechanism ignores the measurement of the social dynamics, the community culture, the neighborhood relationships, and psychological changes of the individual affected by the scheme. (In-depth interview, ID: KT 001, 2006, Direct Translation)

In addition, the social worker also pointed out that the assessment procedure only assesses the social impact before the renewal and there is no ongoing assessment conducted during and after the redevelopment. As such, this mechanism is unable to address the cumulative or indirect impacts of before and after the urban renewal. In this sense, SIA in HK is just capturing a snapshot view of the project area without holistically evaluating the inter-relationships between the project area and its surrounding neighbourhoods. Tang et al. $(2012,103)$ explains that the narrow scope of assessment allows the government to direct the affected residents' opinions "towards the technical items of concepts A and B", in turn, enabling "the government to come up with a consensus, which was successfully legitimized as the collective view of" affected residents.

\section{Limited alternatives for the affected dwellers and over-generalization of the SIA questionnaires}

The main purpose of the people-centred approach stated in the URS is to improve the quality of life of residents in the urban area and to reduce the number of inadequately housed people (The Hong Kong Government 2001, 1). According to (H05-026) SIA report (2006), the SIA questionnaire did not provide an option to retain both the buildings and its sitting tenants. Therefore, affected residents could only choose to receive monetary compensations and rehousing arrangements; however, there was no alternative to retain their 'living rights' to stay in Blue House after revitalization. Additionally, affected residents commented, there was no choice for them to "continue residing within the area upon renovation of the existing building" and "there is no reasonable proposal made to address residents' financial conditions and livelihoods after moving" (Town Planning Board, 2006, 1-2).

According to (H05-026) SIA Report (2006), the questionnaire evaluated the affected dwellers' employment and economic impacts by using "yes or no" and "good or bad" categories. The author argues that the SIA report is over-generalizing the social 
impacts caused by the redevelopment scheme. This overshadowed the unquantifiable and complex nature of social impacts. For instance, the URA and HKHA failed to address the attitudes and psychological changes of the affected dwellers towards employment and community relationships. Those related mitigation measures suggested by the URA and HKHA were "referred to the social service team to follow" ((H05-026) SIA's report 2006, 8).

\section{Conclusion}

The Blue House Case vividly describes how a group of researchers, social workers and affected residents sought to claim their 'rights to living' and 'rights to participate in planning design' in a renewal project in HK. This is a collective action outcome to challenge the dominant discourse of project-induced displacement and reclaims affected residents' collective rights to develop more inclusive space for themselves. In this process, we can see how the thinking of 'right to the city' inspires affected residents to exercise their collective actions to challenge the development claims by the URA/HKHA, reclaims their open space, and determines the future development plan of the Blue House Revitalization Project. The author concludes that, to a small extent, the SIA mechanism can effectively mitigate the social impacts of urban renewal in HK because of three major reasons: first, although the international principles of SIA practice emphasizes minimal displacement of local community, the dominant discourse of 'pro-growth' and 'rehousing' in the HK urban renewal process diminishes the effectiveness of the SIA mechanism to consider alternative project designs or avoid project-induced displacement. On the one hand, a rights-based approach SIA may not sufficiently consider the collective rights of the affected residents to continue living in the project area and determine the future development plan. On the other hand, the SIA mechanism in HK has not sufficiently questioned how the role of government and URA/HKHA has excluded and marginalized the needs of the affected residents. Inspirationally, the 'right to the city' concept motivates academics, affected residents, and local representatives to think beyond property rights by seeking collective 'rights to living'. This demand not only opens up the 
imaginations to consider alternative development formats but also reclaims their rights to 'participate in planning design' of the Blue House and open space usage.

Second, the international standards of the SIA practices stress effective participation through engaging affected residents to understand their needs. However, the delivery of the assessment procedure in $\mathrm{HK}$ is operated in a mechanical manner through conducting CAIR surveys; affected residents fill in a standardized form in order to express their concerns. The author concludes that this mechanical way of survey filling may not effectively address the needs of the affected residents for two major reasons: first, it cannot identify and resolve the engrained conflicts between the pro-growth development and residents' needs. As I have highlighted in Table 1 there are disparities between the assessed impacts in SIA report and the actual needs of the affected residents. Particularly, affected residents' demand for the rights to living was not considered in the SIA mechanism. Second, the author argues that the narrow scope of the SIA assessment procedure enables the URA/HKHA to draw consensus of affected residents, and in turn legitimize and initiate the urban renewal process.

Third, through the thinking of the 'right to the city' and affected residents' comments, the author argues that SIA mechanism in HK is a technical practice of the URA/HKHA to selectively ameliorate the potential social impacts and maintain the efficiency of land production. Unlike most current debates on SIA, this research critically examines how the URA/HKHA legitimizes pro-development discourse displacement through the SIA mechanism. Although the SIA mechanism demonstrates the dominant discourse of displacement, affected residents exercised collective power of opposition to reclaim their rights to living and to determine the future design of the development plan. For international SIA practitioners, the Blue House case not only enriches the theoretical understanding of SIA by questioning whether the definition of rights should not merely be based on 'property', but ought to be further extended to include Lefebvre's right to the city, to consider the definitions of rights as a collective policy outcome and respect the affected residents' rights to living.

To improve the SIA mechanism in HK, it is necessary to develop a complete set of principles and legal enforcement for the implementation of SIA by considering four major areas: (1) define the development values, impacts, and mitigation measures of the 
proposed development project, (2) provide mandatory instructions and steps for the implementation of SIA, particularly developing a Social Impact Management Plan (SIMP) to consider potential impacts holistically, including dispensation of harms and benefits, mitigation strategies, governance structure, and on-going monitoring procedures (Vanclay and Esteves, 2011, 11-12); and (3) protect the rights to the city (i.e. living rights) of the affected residents by drafting the Impact and Benefit Agreements (IBAs) between developers and affected residents. The URA can consider drafting an IBA to negotiate between the developers and affected residents on the development plan, procedures, impacts, and expected benefits and harms after the development. The IBA not only reduces the top-down technocratic control on HK planning system but also provides more room for affected residents to participate in urban renewal and revitalization processes. More importantly, the IBA can help affected residents monitor the SIA process and the process of the urban renewal. 


\section{References}

Blomley, Nicholas K. 2004. Unsettling the city: Urban land and the politics of property: Psychology Press.

Brown, A. 2013. The right to the city: Road to Rio 2010. International Journal of Urban and Regional Research, 37(3), 957-971. Doi: 10.1111/1468-2427.12051

Caine, Ken J., and Naomi Krogman. 2010. "Powerful or just plain power-full? A power analysis of impact and benefit agreements in Canada's north."Organization \& Environment 23 (1): 76-98.

Civic Exchange (2006) The user's guide to the town planning process : how the public can participate in the Hong Kong Planning System. Civic Exchange: Hong Kong

Cooke, Bill, and Uma Kothari. 2001. Participation: The new tyranny?: Zed Books.

Conserve and Revitalise Hong Kong Heritage (2016) Batch II Revitalization Scheme. Accessed October 15, 2016. https://www.heritage.gov.hk/en/rhbtp/ProgressResult2_Blue_House_Cluster.htm

Creswell, J. W. 2007. Research Design: Qualitative, Quantitative, and Mixed Methods Approaches. SAGE Publications.

Denzin N.K. and Lincoln Y.S., 2005. The Sage Handbook of Qualitative Research. $3^{\text {rd }}$ ed. Sage Publications.

Dooling, Sarah. 2009. "Ecological gentrification: A research agenda exploring justice in the city." International Journal of Urban and Regional Research 33 (3):621-639.

Fernandes, E., 2007. Constructing theRight to the City'in Brazil. Social \& Legal Studies, 16(2), pp.201-219.

Galbraith, L., Bradshaw B., \& Rutherford, M. B. 2007. Towards a new supra-regulatory approach to environmental assessment in Northern Canada. Impact Assessment and Project Appraisal, 25(1), 27-41.

Götzmann, Nora, Frank Vanclay, and Frank Seier. 2016. Social and human rights impact assessments: what can they learn from each other?, Impact Assessment and Project Appraisal 34.1: 14-23. doi: 10.1080/14615517.2015.1096036

Harvey, D., 2008. The right to the city. The City Reader, 6, pp.23-40. 
Harvey, David. 2012. Rebel cities: from the right to the city to the urban revolution: Verso Books.

Housing, Planning and Lands Bureau. 2001. Urban renewal strategy, People first: a caring approach to urban renewal. Hong Kong : Planning and Lands Bureau.

Kwok, Yan-chi Jackie. (Eds.) (1998) Xianggang kong jian zhi zao $=$ The production of space in Hong Kong Hong Kong : Crabs Company Limited

Lefebvre, H., 1996. Writings on Cities, translated and edited by Eleonore Kofman and Elizabeth Lebas. Oxford, UK: Blackwell.

Lockie, Stewart. 2001. "SIA in review: setting the agenda for impact assessment in the 21st century." Impact Assessment and Project Appraisal 19 (4):277-287.

Mayer, M., 2009. The 'Right to the City'in the context of shifting mottos of urban social movements. City, 13(2-3), pp.362-374.

Mayer, Margit. 2012, "The "right to the city" in urban social movements." Cities for people, not for profit: Critical urban theory and the right to the city : 63-85.

Mitchell, Don. 2003. The right to the city: Social justice and the fight for public space: Guilford Press.

Momtaz, S. (2006). Public participation and community involvement in environmental and social impact assessment in developing countries. The International Journal of Environmental, Cultural, Economic \& Social Sustainability, 2, 89-97.

Ng, Mee Kam, and Dennis Lai Hang, Hui. 2007. "Practice report: Sustainability impact assessment in Hong Kong and the Pearl River Delta: "both necessary and impossible"?" Impact Assessment and Project Appraisal 25 (3):233-238.

Ng, Mee Kam, Wing Shing Tang, Joanna Lee, and Darwin Leung. 2010. "Spatial practice, conceived space and lived space: Hong Kong's 'Piers saga' through the Lefebvrian lens." Planning Perspectives 25 (4):411-431.

O' Faircheallaigh, Ciaran, and Tony Corbett. 2005. "Indigenous participation in environmental management of mining projects: The role of negotiated agreements." Environmental Politics 14 (5): 629-647.

Omoegun, A.O., 2015. Street Trader Displacements and the Relevance of the Right to the City Concept in a Rapidly Urbanising African City: Lagos, Nigeria (Doctoral dissertation, School of Planning and Geography, Cardiff University). 
Purcell, M., 2002. Excavating Lefebvre: The right to the city and its urban politics of the inhabitant. GeoJournal, 58(2-3), 99-108.

Purcell, M., 2003. Citizenship and the right to the global city: reimagining the capitalist world order. International journal of urban and regional research, 27(3), 564-590.

Staeheli, LA, and D Mitchell. 2008. "The People's Property? Power." Politics and the Public. London: Routledge.

Tang, Wing-Shing. 2008. "Hong Kong under Chinese sovereignty: social development and a land (re) development regime." Eurasian Geography and Economics 49 (3):341361.

Tang, W-S, Chan, K. C., Wong, K. P., Chan, K. W., and Man, P. Y. (2009) The Blueprint of Local Sustainability Practices (地區可持續發展的藍圖實踐. Diqu Ke Chixu Fazhan De Lantu Shijian); In Starting From the Stone Nullah Lane: the twenty years of St. James' Settlement Community Services. Edited by the St James' Settlement: Hong Kong, 114120.

Tang, W.S., Lee, J.W.Y. and Ng, M.K., 2012. Public engagement as a tool of hegemony: The case of designing the new central harbourfront in Hong Kong. Critical Sociology, 38(1), pp.89-106.

Tang, Wing-Shing. 2014. Where lefebvre meets the east: Urbanization in hong Kong. Urban Revolution Now. Henri Lefebvre in Social Research and Architecture, 71-92.

Taylor, CN, CH Bryan, and CG Goodrich. 2004. Social impact assessment: theory, process and techniques. Middleton, WI: Social Ecology Press.

The Antiquities Advisory Board. 2009. "Assessment of the 1, 444 Historic BuildingsDefinition of the Grading." http://www.aab.gov.hk/en/built3.php.

The Antiquities Advisory Board. 2013. "Grade 3 Historic Building in details." http://www.aab.gov.hk/en/built3.php.

The Batch II of Revitalisation Scheme. 2009. Revitalizing Historic Buildings Through Partnership Scheme - Resource Kit. Assessed 22 ${ }^{\text {nd }}$ October 2013. https://www.heritage.gov.hk/en/doc/rhbtp/ResourceKit_BlueHouseCluster.pdf

The Blue House Cluster. 2011. Conservation Management Plan for Viva Blue House Blue House Cluster Revitalization Scheme Hong Kong.

The (H05-026) SIA report - Stone Nullah Lane/Hing Wan Street/ King Sing Street. 2006. Detailed Social Impact Assessment Report - conducted after the publication of the project in Government Gazette on 31 March 2006. Edited by Urban Renewal Authority. Hong Kong. 
The Hong Kong Government. 2001. Urban Renewal Authority Ordinance (Chapter 563). Edited by The Hong Kong Legislative Council.

The Hong Kong Legislative Council. 2010. Legislative Council Panel on Development Progress Report on Heritage Conservation Initiatives Legco, CB (1) 467/10-11(04), p.3. https://www.heritage.gov.hk/en/doc/11.07.07-Panel_Paper(Progress_Report)(E)(clean).pdf

The H-15 Concern Group. 2006. Comments from H15 Concern Group on the Stone Nullah Lane/ Hing Wan Street/ King Street Project of the Hong Kong Housing Society. (Attachment 2 of Town Planning Broad Paper No. 7724. Consideration of representations no. TPB/R/S/H5/URA2/1-1 To 53 and comments No, TPB/R/S/H5/URA2/1-C1 To C4/). Hong Kong: Town Planning Broad.

The Hong Kong Housing Society. 2006. " Project details of Blue House Project ". http://www.hkhs.com/eng/wnew/pr_060331.asp Assessed

The Notice of Gazette (H05-026). 2006. The Notice of Gazette of the Blue House Revitalisation $\quad$ Project. $\quad$ Assessed $15^{\text {th }} \quad$ July 2007. http://www.hkhs.com/preservation/en/pdf/Gazette notice Eng.pdf

The World Charter of the right to the city. 2005. World Charter for the Right to the City: Revision in preparation for Barcelona. World Social Forum - Porto Alegre, 1-11.

Town Planning Board (2006) Urban Renewal Authority Stone Nullah Lane/Hing Wan Stret. King Sing Street Development Scheme Plan No. S/H5/URA2/1 and R/S/H5URA2/1-45, 1-34.

Town Planning Board (2007) Minutes of $873^{\text {rd }}$ Meeting of the Town Planning Board held on $8^{\text {th }}$ December 2006 (Agenda Item 7).

TPB Paper No. 7724 For Consideration by the Town Planning Board on 8.12. 2006. Draft Urban Renewal Authority Stone Nullah Lane/Hing Wan Street/ King Sing Street Development Scheme Plan No. S/H5/URA2/1 Consideration of Representation No. TPB/R/S/H5/URA2/1-1 TO 53, 1-13

Urban Renewal Authority. 2006. Hai Tan Street/Kweilin Street \& Pei Ho Street Development Scheme (SSP/1/003,004,005) - Detailed Social Impact Assessment Report. Hong Kong: Urban Renewal Authority

Urban Renewal Strategy. 2011. People First A District Based and Public Participatory Approach to Urban Renewal, Development Bureau: Hong Kong Special Administrative Region Government, 1-20 
Urban Renewal Authority Ordinance (2001) Chapter 563: L.N. 92 of 2001. Accessed July 15, 2016.

http://www.legislation.gov.hk/blis_pdf.nsf/6799165D2FEE3FA94825755E0033E532/9B A494475B1AC8E8482575EF001B97BF/\$FILE/CAP 563 e b5.pdf

Vanclay, Frank. 2003. "International principles for social impact assessment." Impact assessment and project appraisal 21 (1):5-12.

Vanclay, Frank, and Ana Maria Esteves. 2011. New directions in social impact assessment: conceptual and methodological advances. Edward Elgar Publishing.

Vanclay, Frank., Esteves, Anna. Maria., Aucamp, Ilse. \& Franks, Daniel. 2015 Social Impact Assessment: Guidance for assessing and managing the social impacts of projects. Fargo ND: International Association for Impact Assessment.

\section{Interviews}

In-depth interview, ID: BH001, 2006; In-depth interview, ID: KT001, 2006

In-depth interview, ID: KT002 and KT003, 2008; In-depth interview, ID: BH003, 2013

\footnotetext{
${ }^{1}$ The CAIR survey also investigates the re-housing needs and preferences of the residents and tenants. It assists in the work of the associated authorities such as the Housing Authority and the Hong Kong Housing Society (HKHS) during the acquisition and re-housing stages.

${ }^{2}$ According to the Conserve and Revitalise Hong Kong Heritage (2016), Community Cultural Concern is a charitable institution established in 2006

(https://www.heritage.gov.hk/en/rhbtp/ProgressResult2 Blue House Cluster.htm ).

${ }^{3}$ According to the Conserve and Revitalise Hong Kong Heritage (2016), Heritage Hong Kong Foundation Limited is a charitable institution which was established in 2006 aimING at raising public concerns on heritage and cultural concerns (https://www.heritage.gov.hk/en/rhbtp/ProgressResult2 Blue House Cluster.htm ).

${ }^{4}$ The St. James' Settlement is a non-government organization; provides social services, in Wan Chai District. Social workers in the community development team in St. James' Settlement actively participated in the Blue House preservation campaign and facilitated affected residents to draft out alternative development proposals for the Blue House development.

${ }^{5}$ The aim to conduct CAIR survey is to determine eligibility for ex gratia allowance and re-housing. This survey can prevent and deter imposters from taking residence in the project area afterwards and abusing the re-housing scheme (Housing, Planning and Lands Bureau 2001, 9).
} 